\title{
Medicinal and Nutritional Values of Macrotyloma uniflorum (Lam.) Verdc (Kulattha): A Conceptual Study
}

\author{
Ranasinghe RLDS* and Ediriweera ERHSS \\ Department of Nidana Chikitsa, University of Colombo, Sri Lanka
}

Submission: January 11, 2017; Published: February 13, 2017

*Corresponding author: Ranasinghe RLDS, Department of Nidana Chikitsa, Institute of Indigenous Medicine, University of Colombo, Sri Lanka, Email: rlsandu@gmail.com

Abstract

Macrotyloma uniflorum (Lam.) Verdc commonly known as horse gram is a kind of legume of tropics and subtropics. Its medicinal uses are known to Ayurveda and Sri Lankan traditional physicians for centuries. Present study was undertaken to collect data on medicinal uses and nutritional values of M. uniflorum. Ayurveda pharmacodynamic properties of M. uniflorum are Kashaya Rasa, Laghu, Ruksha, Tikshna Guna, Ushna Veerya and Katu Vipaka. Various medicinal preparations such as Dhanyamla and decoctions are prepared using seeds of M. uniflorum. It is mainly used as a tonic, astringent, diuretic and also recommended in rheumatism, neuralgia and other several diseases. Horse gram seeds are rich in natural phenols; mostly phenolic acids, flavonoids and the major anti-oxidants. Horse gram is considered as animal fodder and its full potential as a part of human diet has not been exploited completely. It can be consumed as seeds, as sprouts or as meal by itself. Horse gram is an excellent source of protein (22-24\%). Seeds contain carbohydrates (57.2\%), fat (1.1\%), vitamins, minerals (3.2\%) and good amount of soluble fibers. Extract of these seeds shows potent anti-adipogenic, anti-hyperglycemic anti-hyper cholesterolemic activities. It acts against oxidative stress. It is concluded that Horse gram can be used as a multifaceted treatment as well as a wholesome food.

Keywords: M. uniflorum; Kulattha; Dhanyamla; Anti-oxidants; Food

\section{Introduction}

Medicinal plants are used as a source of drugs for treatment of various illnesses all over the world, from ancient times to the present day. They serve as sources of important raw materials for manufacturing traditional and modern medicines. Food legumes, an essential component of balanced human diet are recognized as the second most important group of crops after cereals [1]. M. uniflorum (horse gram) is one of the legumes which are having high nutritious as well as ethno-medicinal values in the developing countries. Nowadays, to meet the ever increasing demand for vegetable protein there is an increase demand towards underutilized legumes as new alternate protein sources [2]. Besides nutritional importance; M. uniflorum has been known to its excellent remedial values due to presence of non-nutritive bioactive substances.

The seeds of $M$. Uniflorum contain bioactive substances such as phytic acid, phenolic acid, fiber, enzymatic/proteinase inhibitors which have significant metabolic and physiological effects [3]. Hence, in view of immense medicinal and nutritional importance of M. uniflorum, this review is an effort to compile the information reported on its phytochemical and pharmacological activities. This collection will be helpful to generate interest towards the plant and may be useful in developing new medicinal formulations which are more effective and have more therapeutic values.

\section{Materials \& Methods}

Data was collected from Ayurvedic and Sri Lankan traditional medical texts, interviews conducted with traditional physicians, scientific journals and using web sources. The collected data was analyzed.

\section{Results}

\section{Taxonomic classification [4]}

1. Kingdom: Plantae

2. Class: Magnoliopsida- Dicotyledons

3. Subclass: Rosidae

4. $\quad$ Order- fabales

5. Family: Fabaceae

6. Subfamily: Faboideae 
7. Tribe: Phaseoleae

8. Subtribe: Phaseolinae.

9. Genus: Macrotyloma (Wight \&Arn.) Verdc - macrotyloma

10. Species: Macrotyloma uniflorum (Lam.) Verdc.

\section{Plant profile}

Synonyms of M. uniflorum (Lam.) Verdc [5,6]

Scientific Name: Dolichos biflorus

Sanskrit Name: Kulattha, Kulathika, Sweta beeja

Sinhala Name: Kollu

Tamil Name: Kaanam, Kollu

English Name: Horse gram, madras gram, poor man's pulse

Hindi Name: Kulit, Kultthi

Arabic Name: Habbul Kulth

Chinese Name: Bian Dou

\section{Distribution of M. uniflorum (Lam.) Verdc}
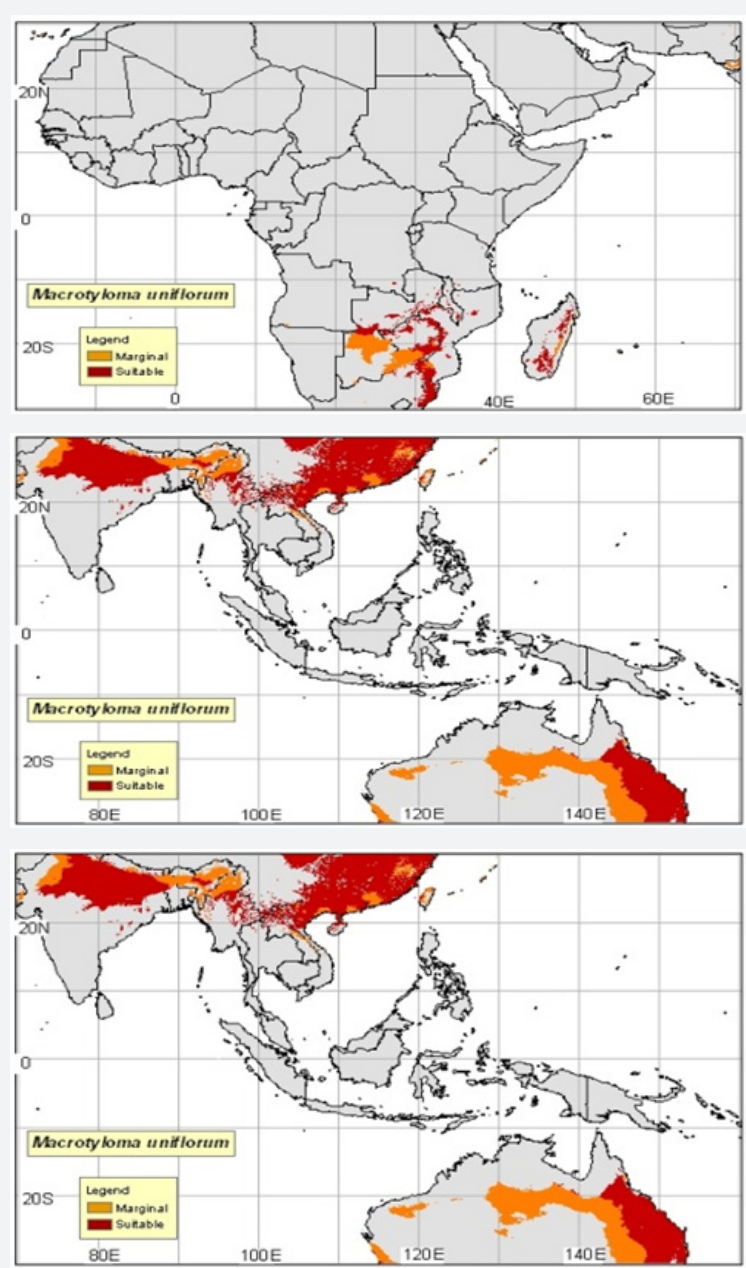

Figure 1: Distribution of $M$. uniflorum
M. uniflorum is native to African countries such as Angola, Ethiopia, Kenya, Namibia, Somalia, South Africa, Tanzania; Asian countries such as Bhutan, China, India, Nepal, Pakistan, Philippines, Sri Lanka and Taiwan and Australasian countries such as Australia [7] (Figure 1).

\section{Morphological Characters}

Morphological characters of M. uniflorum (Lam.) Verdc are given in (Table 1), (Figure 2).

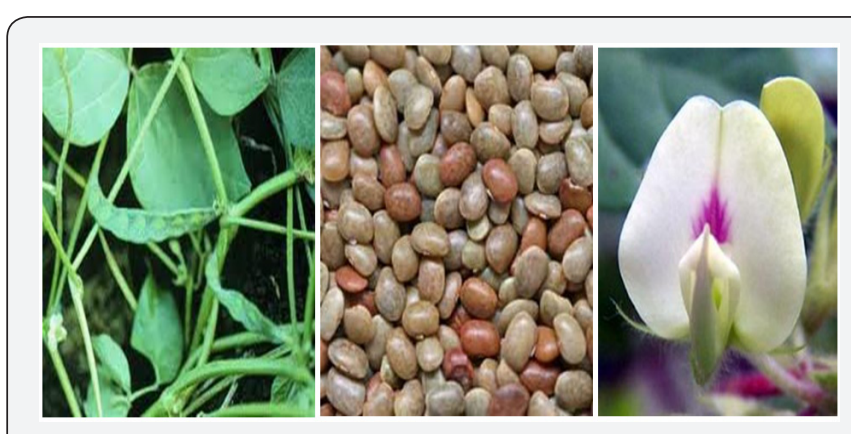

Figure2: M. uniflorum A. Plant and Pods, B. Seeds, C. Flower.

Table 1: Morphological characteristics of the parts of $M$. unifrloum $[8,9]$.

\begin{tabular}{|c|c|}
\hline Part & Characters \\
\hline Habit & $\begin{array}{l}\text { wining, sub-erect annual, } 60 \mathrm{~cm} \text { tall in pure stands, } \\
\text { or } 60-90 \mathrm{~cm} \text { with support framework }\end{array}$ \\
\hline Stem & with cylindrical, slightly hairy to tomentose stems \\
\hline Leaves & $\begin{array}{l}\text { about } 3.5-7.5 \mathrm{~cm} \text { long, trifoliolate; stipules } 7-10 \mathrm{~mm} \\
\text { long }\end{array}$ \\
\hline Leaflets & $\begin{array}{l}\text { acute or slightly acuminate, ovate, rounded at } \\
\text { the base.Terminal leaflet symmetrical, laterals } \\
\text { asymmetrical. } 2-4 \mathrm{~cm} \text { broad, fimbriolate. Softly } \\
\text { tomentose on both surfaces and paler beneath. }\end{array}$ \\
\hline petioles & $2.5 \mathrm{~cm}$ long \\
\hline Flowers & $\begin{array}{c}\text { panicles, nodding, bisexual, } 3 \text { stamens having } \\
\text { spikelets usually having one flower which is jointed } \\
\text { on very short stalks. }\end{array}$ \\
\hline Calyxes & $\begin{array}{c}10.5 \mathrm{~mm} \text { long, } 7-8 \mathrm{~mm} \text { broad, shaped in standard } \\
\text { oblong. Wings about as long as the keel, 8-9.5 mm } \\
\text { long }\end{array}$ \\
\hline Pods & $\begin{array}{l}\text { about } 2.5-6 \mathrm{~cm} \text { long, } 6 \mathrm{~mm} \text { broad, slightly curved, } \\
\text { smooth or tomentose, linear-oblong, with a point } \\
\text { about } 6 \mathrm{~mm} \text { long and shortly stipitate }\end{array}$ \\
\hline Pedicles & $0.3-0.5 \mathrm{~cm}$ long \\
\hline Bracts & lanceolate-linear upto $0.4 \mathrm{~cm}$ long \\
\hline Seeds & $\begin{array}{c}\text { ovoid in shape, } 4-6 \mathrm{~mm} \text { long, } 3-5 \mathrm{~mm} \text { broad. Colored } \\
\text { with pale fawn, light red, brown, or black. Decorated } \\
\text { with faint mottles or with small, scattered black } \\
\text { spots with hilum central. Each pod contains } 5-8 \\
\text { seeds, One kilogram contains about 33,000-75,000 } \\
\text { seeds }\end{array}$ \\
\hline
\end{tabular}




\section{Global Journal of Pharmacy \& Pharmaceutical Sciences}

\begin{tabular}{|c|c|}
\hline \multirow{4}{*}{$\begin{array}{c}\text { Microscopic } \\
\text { features }\end{array}$} & $\begin{array}{c}\text { i. Testa: Epidermis is single layered, thin walled and } \\
\text { shining cells because mucilage in this layer. }\end{array}$ \\
\cline { 2 - 2 } & $\begin{array}{c}\text { ii. Endosperm: Endosperm form bulk of the seed } \\
\text { with thick walled polygonal parenchymatous cells. }\end{array}$ \\
\cline { 2 - 2 } & $\begin{array}{c}\text { iii. Alueron: Outer portion of the seed contains } \\
\text { alueron grains which are protein in nature. }\end{array}$ \\
\cline { 2 - 3 } & $\begin{array}{c}\text { iv. Embryo: In the mid of the seeds, embryo can be } \\
\text { seen which provide nutrition }\end{array}$ \\
\hline
\end{tabular}

\section{Ayurvedic Pharmacodynamic Properties}

Ayurvedic pharmacodynamic properties of M. uniflorum are tabulated below Table 2 [10,11].

Table 2: Ayurvedic Pharmacodynamic Properties of $M$. uniflorum (Lam.) Verdc.

\begin{tabular}{|c|c|}
\hline Property & Description \\
\hline Rasa (taste) & Kashaya (astringent), Madhura (sweet) \\
\hline $\begin{array}{c}\text { Guna } \\
\text { (attributes) }\end{array}$ & Laghu, Ruksha, Teekshna, Ushna \\
\hline $\begin{array}{c}\text { Veerya } \\
\text { (potency) }\end{array}$ & Ushna (hot) \\
\hline $\begin{array}{l}\text { Vipaka (end } \\
\text { result of } \\
\text { digestion) }\end{array}$ & Katu (pungent) \\
\hline $\begin{array}{l}\text { Prabhava } \\
\text { (special } \\
\text { attributes) }\end{array}$ & Bhedana \\
\hline Dosha Karma & KaphaVata Shamaka \\
\hline $\begin{array}{c}\text { Other } \\
\text { properties }\end{array}$ & $\begin{array}{l}\text { Krimighna (anthelminthic), Ashmarinasha } \\
\text { (antilithiatic), Swedakaraka (diaphoretic), } \\
\text { Mutrakaraka (diuretic), Artavajanana } \\
\text { (emmenogogue), Kaphaghna (reduce vitiated } \\
\text { Kapha Dosha) Jvaraghna(febrifuge), Chakshushya } \\
\text { (opthalmic), Lekhana (lipolytic) }\end{array}$ \\
\hline
\end{tabular}

\section{Phytochemicals isolated from M. uniflorum (Lam.) Verdc}

Therapeutic properties of medicinal plants may possibly be due to existence of various phytochemical components. Phytochemical screening studies reveal the existence of flavonoids, urease, glycosides, lenoleic acid, polyphenols, beta Sitosterol, amino acids- glycine, alanine, cysteine, serine, isoflavones, genistein, isoferririn,cumesterol, psoralidin, galactosidase, glucosides and streptogenin [12]. The seeds of M. uniflorum contain extractable total phenolics and tannins. Dry heated samples were found to have considerable amounts of phenolics and tannins than in raw samples [13,14]. Phenolic acids are isolated from the ethanolic extract of the seeds of M. uniflorum by reversed phase HPLC. There were eight phenolic acids components and the most abundant was p-coumaric acid and p-hydroxy benzoic acid. The successive extracts of root, seeds of $M$. uniflorum have revealed the presence of alkaloids, flavonoids, glucosides, lignins, phenols, saponins, tannins and sterols. Alkaloids are the lead molecules of curative importance from Macrotyloma species. Phytochemicals containing in M. uniflorum and their structures are given in (Table $3 \& 4$ ).
Table 3: Phytochemicals isolated from M. uniflorum (Lam.) Verdc.

\begin{tabular}{|c|c|}
\hline Category & Phytoconstituents \\
\hline Anthocyanins & $\begin{array}{c}\text { cyanidin, delphinidin, malvidin, } \\
\text { petunidin [12,13] }\end{array}$ \\
\hline Flavonoids & $\begin{array}{c}\text { daidzein, genistein, kaempferol, } \\
\text { myricetin, quercetin [12,13] }\end{array}$ \\
\hline $\begin{array}{c}\text { Phenolic acids(benzoic } \\
\text { acid derivatives) } \\
\text { gallic acid, protocatechuic acid, } \\
\text { p-hydroxybenzoic acid, syringic acid, } \\
\text { vanillic acid [14] }\end{array}$ \\
\hline $\begin{array}{c}\text { Phenolic acids(cinnamic } \\
\text { acid derivatives) }\end{array}$ & $\begin{array}{c}\text { caffeic acid, chlorogenic acid, ferulic } \\
\text { acid, p-coumaric acid, sinapic acid [14] }\end{array}$ \\
\hline Enzyme source & $\begin{array}{c}\text { a amylase [15] a and b glucosidase [16], } \\
\text { b- N-acetylglucosaminidase, urease [17] }\end{array}$ \\
\hline Haemagglutinins & agglutinin and lectins [18] \\
\hline Tannins & {$[19,20]$} \\
\hline Phytic acid & [18] \\
\hline
\end{tabular}

Table 4: Chemical structures of some compounds isolated from $M$. uniflorum (Lam.) Verdc.

(n)




\section{Traditional uses of M. uniflorum (Lam.) Verdc}

Various parts of the plant M. uniflorum are used in medical systems such as Ayurveda, Siddha and Unani for thousands of years for various ailments both internally and externally.

\section{Internal applications of M. uniflorum (Lam.) Verdc}

The decoction of dry seeds of M. uniflorum is used in traditional medicine for amenorrhea, with rock salt for urolithiasis, bile stones, conjunctivitis, rheumatism, piles, with rock salt for diabetes mellitus, dysuria, colic and flatulence (with Asafoetida), oedema, with pepper for mumps, goiter and phlegmatic conditions [21]. Decoction of seeds is also useful in the management of postpartum syndrome or to promote the discharge of lochia [8]. Infusion of whole seed is an excellent remedy for rheumatic pain and hypertension. Infusion of seeds with cow's milk is useful in the management of helminthes disorders [22]. Kanji (gruel) of dry seeds with jaggery is a remedy for jaundice. Anjana (collyrium) made with powder of seeds is applied for conjunctivitis. Dumapana (inhalation of the smoke) is beneficial for patients suffering from hiccough. The powder of toasted seeds is consumed with curd for gastric ulcers [23]. Intake of horse gram seed powder with some water Table 5: Pharmacological activities of M. uniflorum (Lam.) Verdc. is beneficial in skin rashes and boils. Seeds boiled with water are indicated for obesity. Soup prepared from seeds is administered for haemarrhoides, splenomegaly and hepatomegaly. Decoction of root is given for leucorrhoea. Juice of plant provides a good cure in diarrhea [24].

\section{External applications of M. uniflorum (Lam.) Verdc}

Powder of baked seed is rubbed over the body to manage excessive perspiration. Poultices of seeds are used to induce sweating. Paste of seeds is applied over the skin to enhance complexion. Paste of seeds is also applied for the goiter and mumps [25].

\section{Prepared Medicines by using M. uniflorum (Lam.) Verdc}

The seeds of M. uniflorum are used to prepare drugs such as Kulatthadi Pralepa (paste), Kulatthadi Gruta (ghee), Kulattha Yusha, Dhanyamla (sour gruel) and Dantimuladi Kwatha [26,27].

\section{Pharmacological Investigation}

Pharmacological activities of M. uniflorum (Lam.) Verdc are tabulated in Table 5.

\begin{tabular}{|c|c|c|}
\hline Part & Extract & Pharmacological activity \\
\hline \multirow{2}{*}{ Entire plant } & aqueous and ethanolic & Antihypercholesterolemic [28] \\
\hline & ethyl acetate & Antimicrobial [29-31] \\
\hline \multirow{2}{*}{ Leaves } & aqueous & Antiobesity $[32,33]$ \\
\hline & ethanolic & Antihelminthic $[34,35]$ \\
\hline \multirow{17}{*}{ Seeds } & methanolic & analgesic and anti-inflammatory [36] \\
\hline & & Antidiabetic $[37,38]$ \\
\hline & acetone & Anticholilithiatic [39] \\
\hline & ethanolic & Antihistaminic $[40]$ \\
\hline & hydroalcoholic & anti peptic ulcer [41] \\
\hline & chloroform, methanolic and ethanolic & Antioxidant [42-45], free radical scavenging [46] \\
\hline & alcohol & Antiobesity $[32,33]$ \\
\hline & aquous & antiurolithiatic against calcium oxide crystals [47- 51] \\
\hline & & antiurolithiatic against calcium phosphate crystals [52] \\
\hline & & antiurolithiatic against uric acid crystals [53] \\
\hline & methanolic and ethanolic & Diuretic [54] \\
\hline & butanolic & Haemolitic [55] \\
\hline & methanolic & Hepatoprotective [56] \\
\hline & & larvicidal (a-amylase inhibitors) [57] \\
\hline & & proeinase inhibition $[58,59]$ \\
\hline & hydro-methanolic & nephrotoxicity management [60] \\
\hline & phenols & ACE-1 inhibition (antidiabetic and antihypertensive activity) $[61,62]$ \\
\hline
\end{tabular}


Researches carried out to find Pharmacological activities of $M$. uniflorum (Lam.) Verdc

Anti-hypercholesterolemic effect: Kumar, et al. [28] demonstrated that M. uniflorum extracts have strong activities against hypercholesterolemia and obesity. Antihypercholesterolemic effect of $M$. uniflorum extract is examined in rats by assessing its effects on food consumption, weight gain, serum lipid profile, serum glutamate oxaloacetate transamianse (SGOT), serum glutamate pyruvate transaminase (SGPT) and body fat [28]. Researchers reported that the consumption of ethanol and water extract of the plant for 5 weeks resulted a significant decrease $(p<0.01)$ of total cholesterol (TC), triglycerides, low-density lipoprotein (LDL), very low density lipoprotein (VLDL) SGOT and SGPT levels. There was a significant increase in high-density lipoprotein (HDL) ( $p<0.01)$. They also discovered ethanol extract-treated group has shown a significantly higher fecal excretion of cholesterol level than those treated with water extract. Body weight of rats in the water extract-treated group was significantly lower than that in the ethanol extract-treated group.

Anti-microbial activity: According to Kawsar, et al. [29], Ram, et al. [30] and Gupta, et al. [31] extracts from M. uniflorum seeds had shown significant activity against Bacillus subtilis, Staphylococcus aureus, Escherichia coli and Pseudomonas aeruginosa [29-31].

Anti-helmintic activity: The seeds of $M$. uniflorum have anthelmintic activity which can be beneficial in eliminating worms [34]. Philip, et al. tested he alcohol extracts of M. uniflorum seeds for their anthelmintic activity. These extracts exhibited potent anthelmintic activity against Pheretima posthuma and its activity was comparable with that of the standard, albendazole [35].

Analgesics and anti-inflammatory effect: Giresha et al., assayed the aqueous extracts of $M$. uniflorum coat and pulp by invitro method for inhibition of human secretory phospholipase A2 (sPLA2) as a function of anti-inflammatory activity. The extract effectively neutralized indirect hemolytic activity and showed similar potency in neutralizing the in vivos PLA2 induced mouse paw edema [36].

Anti-diabetic activity: Gupta et al., investigated the antidiabetic effect of $\alpha$-amylase inhibitor isolated from the seeds of M. uniflorum in streptozotocin- nicotinamide induced diabetic mice. They have determined the biochemical parameters such as serum total cholesterol, aspartate aminotransferase (AST) and alanine aminotransferase (ALT) levels [38]. Purwar, et al., found that $M$. uniflorum $\alpha$-amylase inhibitor (MUAI) inhibited both the mouse pancreatic and human salivary $\alpha$-amylase. MUAI reduced the serum glucose level in the treated diabetic mice. Histological findings revealed minimum pathological changes in the treated diabetic mice as compared to the diabetic control [38].

Anti-choliolithic activity: Bigonia, et al. found that $M$. uniflorum seed exerted antilithogenic influence by decreasing the formation of lithogenic bile in mice. Both the methanolic and acetone extracts (ME and $\mathrm{AE}$ ) were capable of decreasing cholesterol hyper-secretion into bile and increasing the bile acid output. The maximum effect was found in the AE as it decreased the papillary proliferation of gallbladder and hepatic fatty degeneration. Antioxidant property of polyphenol and tannin in AE may provide its potential antilithogenic effect [39].

Anti-histaminic activity: Suralkar et al., screened the ethanolic extract of $M$. uniflorum seeds for their anti-histaminic activity by using histamine induced contraction on goat tracheal chain preparation and histamine induced bronchoconstriction in Guinea pigs. Histamine induced contraction of isolated goat tracheal chain preparation was significantly subdued by the ethanolic extract of $M$. uniflorum seeds. The guinea pigs were significantly protected against histamine induced bronchospasm as indicated by delay in the preconvulsivedyspnoea time (PCT) following the exposure of histamine aerosol [39].

I. Anti-peptic ulcer activity: Panda, et al., evaluated the antiulcer activity of the hydroalcoholic extract of the seeds of M. uniflorum (MUSE) and p-coumaric acid against indomethacin (non-steroidal anti-inflammatory drug) and absolute ethanol (necrotizing agent) induced ulcers in rats. A dose-dependent decrease in the ulcer index could be seen in both models after the pre-treatment with MUSE and p-coumaric acid. MUSE and p-coumaric acid elicited significant antioxidant activity by attenuating the ulcer elevated levels of malondialdehyde and restored the ulcerdepleted levels of reduced glutathione and the antioxidant enzymes superoxide dismutase, catalase, glutathione peroxidase and glutathione reductase [40].

II. Anti-oxidant activity: Singh, et al. reported the in-vitro antioxidant activity of ethanolic seed extracts of M. uniflorum [42]. As per Ravishankar, et al. administration of M. uniflorum extract to rabbits with high-fat diet induced oxidative stress, showed improvement in anti-oxidant enzymes such as superoxide dismutase, catalase and increased glutathione concentration [41].

III. Free radical-scavenging capacity: Siddhuraju, et al. revealed that among the various extracts, $70 \%$ acetone extracts of dry-heated samples of brown variety of $M$. uniflorum as well as raw and dry-heated samples of black variety exhibited significantly $(\mathrm{P}<0.05)$ higher hydroxyl radical-scavenging activity. Generally all extracts showed good antioxidant activity (53.3-73.1\%) against the linoleic acid emulsion system but were significantly $(\mathrm{P}<0.05)$ lower than the synthetic antioxidant, BHA (93.3\%) [44].

IV. Anti-urolithiatic activity: $M$. uniflorum was found to be effective in preventing the deposition of the stones in experimental rats. Chaitanya, et al. reported the antiurolithiatic activity of aqueous and alcohol extracts of M. uniflorum seed on ethylene glycol induced urolithiasis 
in albino rats [46]. Das, et al. noticed an excessive urinary excretion of oxalate, calcium and phosphate was resulted after the feeding of ethylene glycol [47]. As per their findings of Atodariya, et al. and Bijarnia, et al. the seeds of M. uniflorum are endowed with significant antiurolithiatic activity and the alcoholic extract of M. uniflorum showed better anti urolithiatic activity than aqueous extract $[48,49]$.

V. Diuretic activity: Ravishankar, et al. explored the diuretic effect of ethanolic seed extracts of M. uniflorum in albino rats. The urine volume, Sodium, Potassium, Chloride and Bicarbonate contents were measured after the oral administration of extracts at doses of $200 \mathrm{mg} / \mathrm{kg}$ and $400 \mathrm{mg} / \mathrm{kg}$. Diuretic effect was significant in experimental animals treated with of $M$. uniflorum extracts compared to the control, Furosemide (5mg/kg) [53].

VI. Hemolytic activity: The 1-butanol extract showed the significant hemolytic activity by mouse erythrocytes. Kawsar, et al. reported the presence of compounds such as methyl ester of hexadecanoic, ethyl ester of hexadecanoic acid mixture and n-hexadecanoic could be constituted a possible chemotaxonomic marker [54].

VII. Hepatoprotective activity: Parmar, et al. discovered the significant hepatoprotactive properties of M. uniflorum seeds against D-Galctosamine and paracetamol induced hepatotoxicity in rats [55].

VIII. Toxicological studies: Kawsar, et al. analyzed the aerial parts of M. uniflorum for their cytotoxicity effects. Crude extracts of dichloromethane $\left(\mathrm{CH}_{2} \mathrm{Cl}_{2}\right)$, ethyl acetate (EtOAc), 1-butanol (1-BuOH) and aqueous $\left(\mathrm{H}_{2} \mathrm{O}\right)$ were screened by using the brine shrimp lethality bioassay technique. Most of the extracts were found to be non-toxic and this indicates that the ethnobotanical use (oral applications) of the $M$. uniflorum is justified [62].

IX. Nutritional Values of $M$. uniflorum (Lam.) Verdc: $M$. uniflorum seeds are known as the poor man's pulse crop in Asian countries, especially India. It is commonly used for both food and fodder. The use of dry seeds of horse gram is limited due to their poor cooking quality. Recently, the US National Academy of Sciences recognized this legume as an upcoming potential food resource [63].

X. Methods of consuming: Seeds are the edible part of the plant and consumed as a whole (boiled) seed, as sprouts, as a curry or as whole meal in Asia, popular especially in southern Indian states. Procedures such as de-husking, germination, cooking, and roasting can be undertaken to enhance the nutritional quality of horse gram [64].

XI. Protein content: Horse gram is the most protein-rich lentil found on the planet. The seeds have twice the protein content as of cereal grains. Mean protein value of horse gram seeds is almost equivalent to winged bean (Psophocarpus tetragonolobus), gram (Cicer arietinum) and soybean (Glycine max) [65,66].

XII. Carbohydrate (CHO) content: $M$. uniflorum seeds contain common and abundant forms of CHO, viz sugars, fibers, and starches. The digestibility of starches as a legume is lower than that of cereal. Contain less carbohydrate (55$65 \%$ ) and energy compared to cereals. CHO available in $M$. uniflorum seeds has low glycemic index [67].

XIII. Fatty acid content: Saturated fatty acids level in the seeds of M. uniflorum is considerably low. It is about $72.49 \%$ unprocessed seeds and about $71.99 \%$ in toasted seeds. Seeds are rich sources of Linoleic acid, an essential fatty acid. Raw seeds contain $45.58 \%$ and toasted seeds contain $40.33 \%$ of Linoleic acid [18].

XIV. Dietary fiber content: Whole grains are the best sources to get fiber into a balance diet. Fibers are of two types, soluble and insoluble. Horse gram seed contains $28.8 \%$ total dietary fibers, mainly insoluble dietary fiber (IDF) $27.82 \%$ and soluble dietary fiber (SDF) $1.13 \%$ with IDF: SDF 24.6 [68]. Horse gram flour contains $16.3 \%$ total dietary fiber $(14.9 \%$ insoluble and $1.4 \%$ soluble and $2.2 \%$ resistant starch) [69]. Seeds of $M$. uniflorum contain more insoluble dietary fiber than kidney bean (Phaseolus aconitifolius) [70].

XV. Micronutrient content: Horse gram has the highest calcium content among pulses. As a legume, Horse gram is deficient in methionine and tryptophan, though it is an excellent source of iron and molybdenum [71,72].

XVI. Anti-oxidant source: The unprocessed horse gram seed is loaded in polyphenols, flavonoids and proteins, the major anti-oxidants which are also available in fruits and other food materials. The greater part of anti-oxidant properties is limited to the outer coat of seed and its removal would eliminate these properties.Macro and micro nutrients composition of dry seeds of M. uniflorum is given in (Table 6 \& 7).

Table 6:The nutritional value of the seeds of M. uniflorum (100g of dry seeds) $[74,75]$.

\begin{tabular}{|c|c|c|c|}
\hline \multicolumn{2}{|c|}{ Macro Nutrients } & \multicolumn{2}{c|}{ Micro Nutrients } \\
\hline Protein & $24.24 \%$ & Calcium & $0.34 \%$ \\
\hline Carbohydrates & $37.15 \%$ & Iron & $32.00 \%$ \\
\hline Fat & $1.10 \%$ & Manganese & $37.00 \%$ \\
\hline Unsaturated fat & $72.49 \%$ & Zinc & $0.28 \%$ \\
\hline
\end{tabular}




\section{Global Journal of Pharmacy \& Pharmaceutical Sciences}

\begin{tabular}{|c|c|c|c|}
\hline Saturated fat & $27.51 \%$ & Phosphorus & $0.27 \%$ \\
\hline Starch & $31.86 \%$ & Magnesium & $0.17 \%$ \\
\hline Sugar & $5.81 \%$ & Copper & $2.1 \%$ \\
\hline Crude fiber & $5.63 \%$ & Vitamin A & $1.4 \%$ \\
\hline Ash & $3.34 \%$ & Vitamin C & $0.7 \%$ \\
\hline Moisture & $8.9 \%$ & Ascorbic acid & $1.5 \%$ \\
\hline & & Niacin (Vitamin B3) & $0.09 \%$ \\
\hline & & Ribloflevin (Vitamin B2) & $0.42 \%$ \\
\hline
\end{tabular}

Table 7: Amino acid and fatty acid composition of M. uniflorum [76].

\begin{tabular}{|c|c|c|}
\hline \multirow{4}{*}{ Amino acids } & Arginine & $8.80 \%$ \\
\cline { 2 - 3 } & Cysteine & $1.96 \%$ \\
\cline { 2 - 3 } & Histidine & $3.15 \%$ \\
\cline { 2 - 3 } & Isoleucine & $6.14 \%$ \\
\cline { 2 - 3 } & Leucine & $8.96 \%$ \\
\cline { 2 - 3 } & Lysine & $8.63 \%$ \\
\cline { 2 - 3 } & Methionine & $1.16 \%$ \\
\cline { 2 - 3 } & Phenylalanine & $6.31 \%$ \\
\cline { 2 - 3 } & Threonine & $3.82 \%$ \\
\cline { 2 - 3 } & Tryptophane & $1.16 \%$ \\
\hline \multirow{4}{*}{ Fatty acids } & Valine & $6.47 \%$ \\
\hline & Linoleic acid & $40.3-45.6 \%$ \\
\hline
\end{tabular}

\section{Amino acid composition of $M$. uniflorum}

A. Anti-nutritional factors: Anti-nutritional factors reduce the bioavailability of nutrients [73]. Horse gram flour also contains such factors viz, trypsin inhibitor (9246 $\pm 18 \mathrm{TIU} / \mathrm{g})$, phytic acid $(10.2 \pm 0.4 \mathrm{mg} / \mathrm{g})$, polyphenols $(14.3 \pm 0.4 \mathrm{mg} \mathrm{GA} / \mathrm{g})$ and oligosaccharides $(26.8 \mathrm{mg} / \mathrm{g})$ [70]. The consumption of horse gram as a human food is limited due to existence of high level of enzyme inhibitors, haemagglutinin activities, oligosaccharides, tannins, polyphenols and phytic acid compared to the other legumes [77,78]. Conventional processing methods such as de-husking, germination, cooking, and roasting have been shown to produce beneficial effects by decreasing the content of undesirable components which results in enhanced acceptability and nutritional quality in addition to optimal utilization of horse gram as human food [79].

M. uniflorum plant is relatively high in iron, but the availability of the iron is reduced by the phylates, tannins and oxalic acid it contains. However these generally considered antinutritional compounds like phytic acid, phenols and tannins are now being measured as potential antioxidants having health promoting effects. The phytic acid has now been shown to possess rich antioxidant, anticarcinogenic and hypoglycaemic activities. Hence depending upon consumer preferences retaining or elimination of these compounds could be facilitated [80].
B. Protease inhibitors: Horse gram habitually contains inhibitors of proteases that reduce the digestibility of dietary proteins. Protease inhibitors form irreversible trypsin enzyme and trypsin inhibitor complex in the intestine. These protease inhibitors resemble other Bowman-Birk protease inhibitors and characterized by low molecular weight, high disulfide content with low content of aromatic amino acids. They can bind as well as inhibit trypsin and chymotrypsin either independently or simultaneously $[81,82]$. Trypsin inhibitor activity is significantly higher in horse gram flour (9246 TIU/g) as compare to chickpea (6452 TIU/g) and cowpea (6981 TIU/g) flour [70]. In germinated seeds trypsin inhibitor activity is $16 \%$ less than that of un-germinated horse gram seeds (950 x 103 TIU/g seed) [83]. As germination induces changes in the Bowman-Birk type proteinase inhibitors in both qualitative and quantitative ways, it facilitates protein hydrolysis for utilization in germination process [84]. Trypsin inhibitors are thermo-labile and their inhibitory activity can be reduced noticeably by thermal treatment [85].

\section{Discussion}

According to Ayurvedic pharmacodynamic properties $M$. uniflorum is capable of pacifying vitiated Vata Dosha by its Madhura Rasa, Ushna Guna and Ushna Veerya. It pacifies vitiated Kapha Dosha, due to Kashaya Rasa, Laghu Guna, Ruksha Guna and Ushna Veerya. Therefore it can be used to treat a variety of 
ailments, originating through a multitude of causes.Seeds are having scientifically proven bioactivities such as anti-diabetic, antihyperlipidemic, diuretic, antioxidant and chemo modulatory. Therefore it can be beneficial in the management of the diseases such as diabetes mellitus, hyperlipidaemia, hypertension and stroke.

M. uniflorum seeds reduce blood sugar levels and post-prandial hyperglycemia, decrease absorption of the carbohydrate from the gut and abundant of soluble fiber. Therefore the seeds are useful in the treatment of diabetes mellitus.Further M. uniflorum seeds reduce serum cholesterol levels, inhibit the hepatic cholesterol genesis, increase excretion of fecal sterol and decrease insulin activates lipoprotein lipase which leads to hypertriglyceridemia. Seeds are also capable to possess hepatoprotective and anti-hyperlipidemic activities. All the above-mentioned effects can contribute potentially toward reduction of hypercholesterolemia and obesity.Seeds of $M$. uniflorum are excellent sources of polyphenols. They are capable of removing free radicals, chelating metal catalysts, activating antioxidant enzymes, reducing tocopherol radicals and inhibiting oxidase. Due to its anthelmintic properties, the seeds of M. uniflorum are useful in treating amoebic dysentry, bowel hemorrhage and colic pains.

\section{Conclusion}

Administration of horse gram can be used as a multifaceted treatment as well as a wholesome food that should be included in our diet on a regular basis.

\section{References}

1. Bhadana VP, Sharma PK, Ansari MA, Bhaishya LK, Punitha P, et al. (2013) Food legumes for livelihood and nutritional security in North Eastern Himalayan region: Prospects and constraints. Indian J Agricultural Sci 83(9): 899-906.

2. Pugalenthi M, Vadivel V, Siddhuraju P (2005) Alternative food/feed perspectives of an underutilized legume Mucuna pruriens varutilis-A review. Plant foods for hum Nutr 60(4): 201-218.

3. Duke JA, Reed CFM (1981) Uniflorum in Handbook of legumes of world economic importance. Plenum Press, USA pp: 345.

4. Fabaceae of North America Update (2011).

5. Dassanayaka (1981) A revised Handbook to the flora of Ceylon (Vol 3), Oxford and IBH Publishing Co PVT Ltd, USA.

6. Dhananjaya J (2006) Handbook of Medicinal Herbs. Deshpande Agrobis, India pp: 195-196.

7. Blumenthal M, Staples L (1993) Origin, evaluation and use of Macrotyloma as forage - a review. Tropical Grasslands 27: 16-29.

8. Jayaweera DMA (1981) Medicinal Plants (Indigenous \& Exotic) used in Ceylon (Part 3). The National Science Council, Sri lanka, pp: 1-297.

9. Verdcourt B (1970) Studies in the Leguminosae-Papilionoideae, Flora of Tropical East Africa, Kew Bulletin 24(3): 507-569.

10. Agnivesha, Charaka Samhita, Chaukhambha Sanskrit Sansthan, Varanasi, 2001, 543.

11. Naḍkarni AK (1927) Indian Materia Medica (2 $\left.2^{\text {nd }} e d n\right)$ (Vol 1) Popular Prakashan, India, pp. 341-343.
12. Morris JB (2008) Macrotyloma axillare and M uniflorum: descriptor analysis, anthocyanin indexes, and potential uses. Genetic Resources and Crop Evolution 55(1): 5-8.

13. John Bradley Morris, Ming Li Wang, Michael A Grusak, Brandon Tonnis (2013) Fatty Acid, Flavonol, and Mineral Composition Variability among Seven Macrotyloma uniflorum (Lam) Verdc Accessions Agriculture 3(1): 157-169.

14. Kawsar S, Huq E, Nahar N, Ozeki Y (2008) Identification and quantification of phenolic acids in Macrotyloma uniflorum by reversed phase HPLC. American Journal of Plant Physiology 3(4): 165-172.

15. Maryada Garg, Anoop K Dobriyal (2011) Partial purification and characterization of some low molecular weight $\boldsymbol{\alpha}$-amylases from Dolichos biflorus. Journal of Applied and Natural Science 3(1): 75-77.

16. Meyer D, Bourrillon R (1973) Glycosidases of Dolichos biflorus. Isolation and general properties. Biochimie 55(1): 5-10.

17. Natarajan K (1995) Kinetic study of the enzyme urease from Dolichosbiflorus. J Chem Educ 72(6): 556-557.

18. John Bradley Morris, Ming Li Wang, Michael A Grusak, Brandon Tonnis (2013) Fatty Acid, flavonol, and mineral composition variability among seven M uniflorum (Lam) Verdc accessions. Agriculture 3: 157-169.

19. Bolbhat SN, Dhumal KN (2012) Physiological, biochemical and enzymological studies in horsegram Macrotylomauniflorum (Lam). Verdc Int J of Advanced Scientific and Tech Res 6(2): 679-689.

20. Laura Bravo, Perumal Siddhuraju, Fulgencio Saura-Calixto (1999) Composition of underexploited Indian pulses. Comparison with common legumes. Food Chemistry 64(2): 185-192.

21. Chunekar KC, Pandey GS (1998) Bhavaprakash Nighantu of Sri Bhavamisra (c.1500-1600 AD). ChaukhambaBharati Academy pp: 984.

22. Kamat SD (2002) DhanvantariNighanthu. Chaukhamba Sanskrit Paristhan India.

23. Bhagawan Dash, Kashyap L (1980) Materia Medica of Ayurveda. Concept Publishers Company, India.

24. Yadava ND, Vyas NL (1994) Horsegram. In: Arid legumes, Agro botanical publishers, India. pp: 64-75.

25. Ayurveda pharmacopeia (Vol 1 Part 3)(1969). Department of Ayurveda, Sri Lanka.

26. Ayurveda pharmacopeia (Vol 1 Part 1) (1969) Department of Ayurveda, Sri Lanka.

27. Osuthuru Visithuru (1994) Vol 2. Colombo: Department of Ayurveda pp 319.

28. Kumar DS, Prashanthi G, Avasarala H, Banji D (2013) Anti-hyper cholesterolemic effect of M. uniflorum (Lam.) Verdc (Fabaceae) extract on high-fat diet-induced Hypercholesterolemia in Sprague-Dawley Rats. J Diet Suppl 10(2): 116-128.

29. Kawsar SMA, Seraj Uddin M, Huq E, Nahar N, Yasuhiro Ozeki (2008) Biological investigation of M. uniflorum Linn. extracts against some pathogens. Journal of Biological Sciences 8(6): 1051-1056.

30. Jeevan Ram A, Bhakshu LM, Venkata Raju RR (2004) In-vitro antimicrobial activity of certain medicinal plants from eastern ghats, India, used for skin diseases. J Ethnopharmacol 90(2-3): 353-357.

31. Gupta SK, et al. (2005) Anti-microbial activity of Dolichos biflorus seeds. Indian J Nat Prod 21: 20-21.

32. Sengupta K, Mishra AT, Rao MK, Sarma KV, Krishnaraju AV, et al. (2012) Efficacy of an herbal formulation LI10903F containing Dolichos biflorus and Piper betle extracts on weight management. Lipids Health Dis 11(1): 176. 


\section{Global Journal of Pharmacy \& Pharmaceutical Sciences}

33. Bharathi V, Anand V (2014) Anti-Obesity effect of M. uniflorum leaves extract on rats fed on hypercaloric diet. World Journal of Pharmacy and Pharmaceutical Sciences 3(5): 1500-1504.

34. Ansa Philip, Athul PV, Ajmal Charan, Afeefa TP (2009) Anti-helmintic activity of seeds of M. uniflorum. hygeia 1(1): 26-27.

35. Varicola Karuna Sree, Meda Soundarya, Maddala Ravikumar, Tiyyagura Ravichandra Reddy, Nelluri Kanaka Durga Devi (2014) In-vitro screening of Macrotylomauniflorum extracts for anti-oxidant and anthelmintic activities. Journal of Pharmacognosy and Phytochemistry $3(4): 6-10$.

36. Giresha A S, Narayanappa M, Vikram Joshi, Vishwanath BS, Dharmappa KK (2015) Human secretory phospholipase A2 (spla2) inhibition by aqueous extract of Macrotylomauniflorum (seed) as an antiinflammatory activity. International journal of pharmacy and pharmaceutical sciences 7(Suppl 1).

37. Parthsarthi, Purwar B, Saxena Y (2013) Effect of Dolichosbiflorus on blood sugar and lipids in diabetic rats. Indian Journal of Physiol Pharmacol 57(1): 63-71.

38. Gupta LH, Badole SL, Bodhankar SL, Sabharwal SG (2011) Anti-diabetic potential of $\alpha \alpha$-amylase inhibitor from the seeds of M. uniflorum in streptozotocinnicotinamide-induced diabetic mice. Pharm Biol 49(2): 182-189.

39. Bigoniya P, Sourabh Bais, Brijesh Sirohi (2014) The effect of M. uniflorum seed on bile lithogenicity against diet induced cholelithiasis on mice. Ancient Science of Life 33(4): 242-251.

40. Suralkar AA, Kasture SB (2013) Evaluation of Anti-histaminic activity of Dolichos biflorus. International Journal of Pharma and Bio Sciences 4(4): 346-352.

41. Vandana Panda, Swetha Suresh (2015) Gastro-protective effects of the phenolic acids of M. uniflorum (horse gram) on experimental gastric ulcer models in rats. Food Bioscience 12: 34-46.

42. Renu Singh, Manoj Kumar Singh, Lovy Raj Chandra, Deepa Bhat, Manmeet Singh Arora, et al. (2012) In-vitro Anti-oxidant and free radical scavenging activity of M. uniflorum (Gahat dal) from Kumauni region. International Journal of Fundamental and Applied Sciences 1(1): 9-11.

43. Ravishankar K, Priya P (2012) In-vitro anti-oxidant activity of ethanolic seed extracts of M. uniflorum and Cucumismelo for therapeutic potential. International Journal of Research in Pharmacy and Chemistry 2(2): 442-445.

44. Marimuthu M, Krisnamoorthi K (2013) In-vitro anti-oxidant potential of chlorofrom seed extract of underutilized/less edible South Indian legumes. PHARMANEST- An International Journal of Advances in Pharmaceutical Sciences 4(4): 647-658.

45. Kottai Muthu A, Sethupathy S, Manavalan R, Karar PK (2006) Antioxidant potential of methanolic extract of D. biflorus in high fat diet fed rabbits. Indian J Pharmacol 38(2): 131-132.

46. Perumal Siddhuraju, Sellamuthu Manian (2007) The antioxidant activity and free radical-scavenging capacity of dietary phenolic extracts from horsegram seeds. Food Chem 105(3): 950-958.

47. Das I (2005) In-vitro inhibition and dissolution of calcium oxalate by edible plant Trianthema monogyna and pulse M. uniflorum extracts. Journal of Crystal Growth 273(3-4): 546-554.

48. Chaitanya DAK, Santosh kumar M, Manohar Reddy A, Ramesh A (2010) Anti-urolithiatic activity of $M$. uniflorum seed extract on ethylene glycol induced urolithiasis in albino rats. Journal of Innovative trends in Pharmaceutical Sciences 1(5): 216-226.

49. Unnati Atodariya, Roshni Barad, Siddhi Upadhyay, Umesh Upadhyay (2013) Anti-urolithiatic activity of Dolichos biflorus seeds. Journal of
Pharmacognosy and Phytochemistry 2(2): 209-213.

50. Bijarnia R, Kaur T, Singla SK, Tandon C (2009) A Novel Calcium Oxalate Crystal Growth Inhibitory Protein from the Seeds of Dolichos biflorus (L.) Protein J 28(3-4): 161-168.

51. Kieley S, Dwivedi R, Monga M (208) Ayurvedic medicine and renal calculi. J Endourol 22(8): 1613-1616.

52. Garimella TS, Jolly CI, Narayanan S (2001) In-vitro studies on antilithiatic activity of seeds of Dolichos biflorus Linn. and rhizomes of Bergenia ligulata Wall. Phytother Res 15(4): 351-355.

53. Ahmad J (1992) Inhibitory effects of aqueous extracts of natural products on the crystallization of urinary lithiasis in-vitro (Part III) Uric acid. Pakistan Journal of Biochemistry 25: 65-70.

54. Ravishankar K, Priya P (2012) Evaluation of diuretic effect of ethanolic seed extracts of Macrotyloma uniflorum and Cucumis melo in rats. International Journal of Pharma \& Bio Sciences 3(3): 251-255.

55. Kawsar SMA, Mostafa G, Huq E, Nahar N, Ozeki Y (2009) Chemical constitutions and hemolytic activity of $\mathrm{M}$. uniflorum. International Journal of Natural and Engineering Sciences 3(1): 69-72.

56. Parmar H (2012) To investigate hepatoprotective activity of $M$. uniflorum seed extract on paracetamol and d-galactosamine induced liver toxicity in albino rats. International Journal of Pharmacological Research 2(2): 86-91.

57. Laxmi Gupta, Sudhakar Deshpande, Vrushali Tare, Sushma Sabharwal (2011) Larvicidal activity of the $\alpha$-amylase inhibitor from the seeds of M. uniflorum (Leguminosae) against Aedesaegypti. International Journal of Tropical Insect Science 31(1-2): 69-74.

58. Ramasarma PR Appu Rao AG, Rajagopal Rao D (1995) Role of disulfide linkages in structure and activity of proteinase inhibitor from horsegram. Biochimica et Biophysica Acta (BBA)-Protein Structure and Molecular Enzymology 1248(1): 35-42.

59. Sreerama Y, Das JR, Rao DR, Gowda LR (1997) Double headed trypsin/ chymotrypsin inhibitors from horse gram (Dolichos biflorus): purification, molecular and kinetic properties. Journal of Food Biochemistry21(1): 461-477.

60. Sarmistha Saha, Ramtej J Verma (2012) Efficacy Study of Dolichos biflorus in the Management of Nephrotoxicity. Asian Pacific Journal of Tropical Biomedicine 2(3): 1471-1476.

61. Wagner H (1991) Evaluation of natural products as inhibitors of angiotensin-I converting enzyme (ACE). Pharmaceutical and Pharmacological Letters 1: 15-18.

62. Chen CH, Lin JY, Lin CN, Hsu SY (1992) Inhibition of angiotensin-I converting enzyme by tetrahydroxyxanthones isolated from Tripterospermum lanceolatum. J Nat Prod 55(5): 691-695.

63. Kawsar SMA, Huq E, Nahar H (2008) Cytotoxicity Assessment of the Aerial Parts of M. uniflorum. International Journal of Pharmacology 4(4): 297-300.

64. Washington DC (1978) Mothbean in tropical legumes: resources for the future. National Academy of Sciences pp: 75.

65. Gopalan C (1989) Nutritive value of Indian foods. National Institute of Nutrition, ICMR, India.

66. Mushtari B (1977) Varietal difference in protein of horsegram (Dolichosbiforus Linn.) Mysore J Agric Sci 11: 521-524.

67. Prasad SK, Singh MK (2015) Horsegram-An underutilized nutraceutical pulse crop: a review. J Food Sci Technol 52(5): 2489-2499.

68. Bhartiya A, Aditya JP, Kant L (2015) Nutritional and remedial potential of an underutilized food legume horsegram a review. The Journal of Animal \& Plant Sciences 25(4): 908-920. 


\section{Global Journal of Pharmacy \& Pharmaceutical Sciences}

69. Khatoon N, Prakash J (2004) Nutritional quality of microwave-cooked and pressure cooked legumes. Int J Food Sci Nutr 55(6): 441-448.

70. Sreerama YN, Vadakkoot B Sashikala, Vishwas M Pratape, Vasudeva Singh (2012) Nutrients and antinutrients in cowpea and horsegram flours in comparison to Evaluation of their flour functionality. Food Chemistry 131: 462-468.

71. Kawale SB, Sercan Kadam, Chavan UD, Chavan JK (2005) Effect of processing on insoluble dietary fiber and resistant starch in kidney bean and horsegram. J Food Sci Technol 42: 361-362.

72. Kirtikar KR, Basu BD, Kirtikar basu (1991) Indian medicinal plants. International Book Distributors India 1(4).

73. Ahmed S, Hasan M, Zafar Am (2015) Basic composition and caloric contents of M. uniflorum, Phaseolus lunatus and P. vulgaris legume flours. Pharmanest - An International Journal of Advances in Pharmaceutical Sciences 6(5): 2984-2987.

74. Jayashri hiremath, Sunanda sharan, Vishawanath KP (2001) Chemical Composition and Functional Properties of Some Important Genotypes of Horsegram. Karnataka J Agric Sci 14(4): 943-946.

75. Bolbhat S, Dhumal K (2014) Mineral constituents in seeds of horsegram mutants. International Journal of Advanced Scientific and Technical Research 4(3): 15-21.

76. Kadam SS, Salunkhe DK (1985) Nutritional composition, processing, and utilization of horsegram and moth bean. Crit Rev Food Sci Nutr 22(1): 1-26.

77. Jain AK, Sudhir Kumar, Panwar JDS (2009) Anti-nutritional factors and their detoxification in Pulses- A review. Agricultural Reviews 30 (1) 64-70.
78. Dhumal KN, Bolbhat SN (2012) Induction of genetic variability with gamma radiation and its applications in improvement of horsegram. Gamma Radiation 207-228.

79. Sharma AS (2011) Horsegram (Macrotylomauniflorum (L.)): A legume to reckon with for health and nutrition.

80. Rajeev Bhat, Karim AA (2009) Exploring the nutritional potential of wild and underutilized legumes. Comprehensive Reviews in Food Science and Food Safety 8(4): 305-331.

81. Singh RR, Appu Rao AG (2002) Reductive unfolding and oxidative refolding of a Bowman-Birk inhibitor from horsegram seeds; evidence for 'hyper reactive' disulfide bonds and rate-limiting nature of disulfide isomerization in folding. Biochem Biophys Acta 1597(2): 280-291.

82. Ramasarma PR, Appu Rao AG, Rajagopal Rao D (1994) Kinetic and structural studies on the interaction of proteinase inhibitor from Dolichos biflorus. J Agric Food Chem 42(10): 2139-2146.

83. Subbulakshmi G, Ganesh Kumar, Venkataraman (1976) Effect of germination on the carbohydrates, proteins, trypsin inhibitor, amylase inhibitor and haemaggliutinin in horsegram and moth bean. Nutrition Reports International 13(1): 19-32.

84. Yadahalli N, Sreerama, Lalitha R Gowda (1998) Bowman-Birk type proteinase inhibitor profiles of horsegram during germination and seed development. J Agric Food Chem 46(7): 2596-2600.

85. Liener IE (1994) Implications of anti nutritional components in soybean foods. Crit Re Food Sci Nutr 34(1): 31-67.

\section{Your next submission with Juniper Publishers will reach you the below assets}

- Quality Editorial service

- Swift Peer Review

- Reprints availability

- E-prints Service

- Manuscript Podcast for convenient understanding

- Global attainment for your research

- Manuscript accessibility in different formats ( Pdf, E-pub, Full Text, Audio)

- Unceasing customer service

Track the below URL for one-step submission https://juniperpublishers.com/online-submission.php 